\title{
Effect of preharvest application of different chemicals and plant growth regulators on biochemical parameters of mango (Mangifera indica L.) var. Amrapali
}

\author{
Pradeep Kumar Vishwakarma* AND M. M. Masu \\ Department of Horticulture, B. A. College of Agriculture, Anand Agricultural University, \\ ANAND (GUJARAT) INDIA (Email : pradeepkumar5953@gmail.com)
}

\begin{abstract}
The present investigation on effect of preharvest application of different chemicals and plant growth regulators on biochemical parameters of mango (Mangifera indica L.) var. Amrapali was carried out during summer season of the year 2016 at Anand. The plants of mango were preharvest sprayed with $\mathrm{CaCl}_{2} 1 \%, \mathrm{CaCl}_{2} 2 \%, \mathrm{Ca}\left(\mathrm{NO}_{3}\right)_{2} 1 \%, \mathrm{Ca}\left(\mathrm{NO}_{3}\right)_{2} 2 \%, \mathrm{KNO}_{3} 1 \%, \mathrm{KNO}_{3}$ $2 \%, \mathrm{GA}_{3} 25 \mathrm{mg} / \mathrm{l}, \mathrm{GA}_{3} 50 \mathrm{mg} / \mathrm{l}$, ethrel $0.1 \mathrm{ml} / \mathrm{l}$ and ethrel $0.2 \mathrm{ml} / \mathrm{l}$. There were eleven treatment embedded in Completely Randomized Design replicated thrice. Thirty three uniform size tree of mango were selected. Fresh and mature fruits were harvested from trees which was preharvest sprayed with different chemicals and plant growth regulators and stored under ambient storage condition. Among all the treatment $\mathrm{CaCl}_{2} 2 \%$ recorded significantly highest total soluble solids, reducing sugar, total sugar, non-reducing sugar, ascorbic acid and minimum acidity consistently at harvest and every three days interval upto last ripening stage i.e. $4^{\text {th }}$ day, $8^{\text {th }}$ day, $12^{\text {th }}$ day and $16^{\text {th }}$ day under ambient storage condition.
\end{abstract}

Key Words : $\mathrm{CaCl}_{2}, \mathrm{GA}_{3}$, Fruit quality

View Point Article : Vishwakarma, Pradeep Kumar and Masu, M.M. (2018). Effect of preharvest application of different chemicals and plant growth regulators on biochemical parameters of mango (Mangifera indica L.) var. Amrapali. Internat. J. agric. Sci., 14 (1) : 92-96, DOI: 10.15740/HAS/IJAS/14.1/92-96.

Article History : Received : 26.06.2017; Revised : 12.11.2017; Accepted : 25.11.2017

\footnotetext{
* Author for correspondence:
} 